\title{
Body size and stable isotope composition of zooplankton in the western tropical Atlantic
}

\author{
Guerra Araújo Abrantes De Figueiredo Gabriela ${ }^{1}$, Schwamborn Ralf 1, ${ }^{\text {, }}$, Bertrand Arnaud ${ }^{2,3}$, \\ Munaron Jean-Marie ${ }^{4}$, Le Loch Francois ${ }^{4}$
}

\begin{abstract}
1 Department of Oceanography, Federal University of Pernambuco, Recife, Brazil
2 Programa de pós-graduação em Ecologia, Universidade Federal Rural de Pernambuco, Recife, Brazil

3 Institut de Recherche pour le Développement (IRD), MARBEC, Univ Montpellier, CNRS, Ifremer, IRD, Sète, France

${ }_{4}^{4}$ Institut de Recherche pour le Développement, Univ Brest, CNRS, IRD, Ifremer, LEMAR, IUEM, F29280 Plouzané, France
\end{abstract}

* Corresponding author : Ralf Schwamborn, email address : ralf.schwamborn@ufpe.br

\begin{abstract}
:
Size-based approaches are paramount tools for the study of marine food webs. Here, we investigated the relationship between zooplankton body size, stable isotope composition and trophic level (TL) along a large-scale onshore-offshore gradient in the western tropical Atlantic. Samples were obtained on the Brazilian continental shelf, slope and in oceanic waters (off Fernando de Noronha archipelago and Rocas Atoll) in September and October 2015. Zooplankton was sieved into five size fractions. Zooplankton was dominated by copepods, except for the largest $(>2000 \mu \mathrm{m})$ size fraction, that showed a high biovolume of chaetognaths, decapods, and fish larvae. Maximum zooplankton abundance and biovolume was found at the continental slope. POM showed consistently lower $\delta 13 \mathrm{C}$ than zooplankton, indicating a selective use of 13C-rich primary food sources by zooplankton. Particulate organic matter (POM) was more 13Cenriched in shelf areas (average: $-22.8,-23.6$ and $-24.3 \%$ at the shelf, slope and oceanic islands, respectively), probably due to the higher abundance of diatoms nearshore. POM had $\delta 15 \mathrm{~N}$ values between 2.5 and $6.9 \%$ (average: $4.0,4.9$ and $4.2 \%$ at the shelf, slope and oceanic islands, respectively). Zooplankton $\delta 15 \mathrm{~N}$ and TL increased with body size. The $\delta 15 \mathrm{~N}$ of the $200-500 \mu \mathrm{m}$ size fraction was used as baseline for TL estimation. Oceanic areas (average baseline $\delta 15 \mathrm{~N}=5.8 \% 0 \pm 0.52, \mathrm{n}=14$ ) showed a higher baseline $\delta 15 \mathrm{~N}$ than the shelf (average $=3.9 \% \pm 0.69, n=9$ ) and the slope areas (average $=3.1 \% \pm \pm 0.93, n=9$ ). In spite of differing baselines, the $\delta 15 \mathrm{~N}$ data produced a consistent pattern of log-linear increase in TL with increasing size, in all areas. The choice of input trophic enrichment factor (TEF) values only slightly changed the log10 (body size) vs TL slopes, but this choice had a considerable effect on the estimates of predator/prey size ratio (PPSR) and predator/prey mass ratio (PPMR). Using a TEF above 2.3 leads to unrealistic PPSR and PPMR estimates. Overall average slope was $0.59 \pm 0.08$ $\mathrm{TL} \mu \mathrm{m}-1$ with $\mathrm{TEF}=2.3$ and $0.42 \pm 0.07 \mathrm{TL} \mu \mathrm{m}-1$ with $\mathrm{TEF}=3.2$.
\end{abstract}




\section{Highlights}

- Maximum zooplankton abundance and biovolume was found at the continental slope. POM showed lower $\delta^{13} \mathrm{C}$ than zooplankton, indicating selective feeding. Zooplankton $\delta^{15} \mathrm{~N}$ and trophic level increased with body size. Using a $\delta^{15} \mathrm{~N}$ trophic enrichment factor above 2.3 leads to unrealistic estimates.

Keywords : Plankton, $\delta 13 \mathrm{C}, \delta 15 \mathrm{~N}$, Size classes, Trophic level, Predator / prey mass ratio 


\section{Introduction}

A large number of factors influence the functioning of pelagic ecosystems, including the spatio-temporal variability of physical and chemical variables, as well as dynamic interactions between species. These processes shape species distribution and trophic structure. Body size, which is easily and quickly determined, is considered one of the most important determinants of ecosystem structure (Jennings et al., 2007; Petchey et al., 2008) since metabolic requirements, fond selection, growth and reproductive capacity are related to body size. Siz - $`$ sed analyses are therefore paramount tools for studying marine food webs (Jen. ings et al., 2001; Bănaru et al., 2014; Hunt et al., 2015; Yang et al., 2016). In pe'ay ‘ marine food webs, predators are generally larger than their prey (Cohen et a 1 ,93) and trophic level (TL) is almost exclusively size-based. Thus, pelagic $n a^{r}$ ne ecosystems can be well described by a loglinear size spectrum, where abunance continuously decreases with size, due to the energy loss in trophic transferc (1\%.tt and Denman, 1977; Fry and Quinones, 1994; Jennings et al., 2002; Hu. ${ }^{+}$et al., 2015). This theory was reinforced by Fry and Quinones (1994), who e tirlated zooplankton TLs with stable carbon and nitrogen isotopes, and detern. neu now TLs changed with body size. Their results supported the arguments that trophic organization and metabolism are important structuring forces. Analyzes of pelagic organisms aggregating them by size, may contribute to the understanding of the functioning of pelagic ecosystems.

Stable isotope analysis (SIA) is widely used to elucidate trophic relationships in marine food webs (Post, 2002; Hunt et al., 2015). Nitrogen and carbon stable isotopes $\left(\delta^{15} \mathrm{~N}\right.$ and $\left.\delta^{13} \mathrm{C}\right)$ are natural tracers that incorporate information on trophic position and food source (Fry, 2006; Wang et al., 2013). For instance, $\delta^{15} \mathrm{~N}$ increases with trophic 
position (Post, 2002), i.e., predators are generally ${ }^{15} \mathrm{~N}$-enriched in relation to their prey (Minagawa and Wada, 1984). Conversely, carbon stable isotopes $\left(\delta^{13} \mathrm{C}\right)$ are incorporated by organisms with less modification between predators and prey (McConnaughey and McRoy, 1979). Since predator $\delta^{13} \mathrm{C}$ values do not differ too much from their food sources (Miller et al., 2008), they can be used as tracers of food sources or feeding areas.

Lower trophic levels, such as most plankton organisms, are important for SIA in marine environments, since they are very sensitive to phycicaı processes that result in

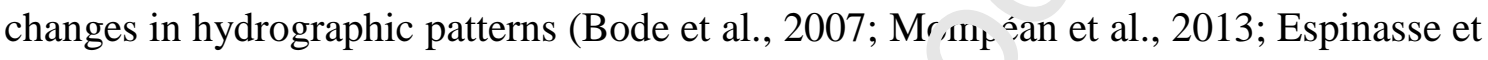
al., 2014). Zooplankton plays a key role in pelagir ec systems by connecting primary producers to higher trophic levels (Saiz et al., 20u - Guidi et al., 2016; Gove et al., 2016). Understanding the structure and $t_{2} \mathrm{c}^{+}$on of zooplankton communities is necessary to understand their role $n$ r.arine ecosystems (Yang et al., 2017). SIA provides a tool to analyze zooplank $n$ n food webs and to measure trophic relationships between food web components ( ang et al., 2016). Combined with size-based approaches, SIA can provic' coınprehensive understanding of zooplankton food webs (Jennings et al., 2002; Ràıır’. et al., 2014; Espinasse et al., 2014; Yang et al., 2016).

The western tropi al Atlantic off northeastern Brazil is mostly dominated by the warm oligotrophic waters that are derived from the south equatorial current (SEC). This region comprehends the extension from the shelf, slope and slope, seamounts and oceanic islands, all with low levels of nutrient supply and productivity and high zooplankton diversity (Boltovskoy et al., 1999). Numerous studies have investigated zooplankton communities in this region, most of which focusing on community structure, abundance diversity (e.g., Neumann-Leitão et al., 1999; Diaz et al., 2009; Brandão et al., 2013; Lira et al., 2014; Santana et al., 2018), and size spectra (Marcolin 
et al., 2013). In this region, the stable isotope composition $\left(\delta^{13} \mathrm{C}\right.$ and $\left.\delta^{15} \mathrm{~N}\right)$ of zooplankton and particulate organic matter (POM) has been investigated in mangrove estuaries, on the shelf and at the adjacent slope, revealing that any measurable estuarine influence was limited to the line of intertidal coastal reefs, approximately $10 \mathrm{~km}$ from the coast (Schwamborn et al., 1999, 2002).

In this study, we investigate the relationship between body size and stable isotope composition of zooplankton communities in the western tro ical Atlantic, to understand the relationship between trophic levels and body size, a $d$ te test the hypothesis that there are differences in zooplankton trophic structurc am ong different environments along a large-scale onshore-offshore gradient.

\section{Methodology}

\subsection{Sampling strategy}

Zooplankton and particı lat organic matter (POM) were sampled on the continental shelf, at the slope, and in nce: nic waters off northeastern Brazil (Figure 1). Two oceanic island systems wer si d:ed: Fernando de Noronha archipelago (FN) and Rocas Atoll (RA, Figure 1). Samples were collected between September 29 and October 21, 2015, during the Acoustic along the Brazilian coast cruise (ABRACOS, Bertrand, 2015) conducted on board R/V ANTEA.

At each station, vertical profiles of conductivity, temperature and chlorophyll a fluorescence were acquired using a Seabird SBE911+ CTD probe. Zooplankton sampling was conducted by towing a regular bongo frame with four nets fitted with mesh sizes of 64 $\mu \mathrm{m}$ (30 cm mouth opening diameter), $120 \mu \mathrm{m}$ (30 cm diam.), $300 \mu \mathrm{m}(60 \mathrm{~cm}$ diam.) and 
$500 \mu \mathrm{m}(60 \mathrm{~cm}$ diam.). At each station, two oblique hauls were conducted between 200 meters and the surface or between 10 meters from the bottom to the surface at locations with less than $200 \mathrm{~m}$ of bottom depth. A total of 14 and 18 samples were collected during day night, respectively.

A Hydro-Bios flowmeters were fixed inside the net opening of each net to estimate filtered volume. Seawater samples for particulate organic matter (POM) were collected at the surface $(3 \mathrm{~m})$ and at the depth of maximum fluorescencr using a CTD/rosette equipped with Niskin bottles. A total of 8 liters of water were filtt ed on a $47 \mathrm{~mm}$ diameter Whatman GF/F filter. In the laboratory, all filter sample $₹ \mathrm{w} \epsilon$ re dried at $40^{\circ} \mathrm{C}$ during $36 \mathrm{~h}$.

\subsection{Size spectra}

Oblique bongo haul samples, taken sir.ulı..eously with $120 \mu \mathrm{m}, 300 \mu \mathrm{m}$ and 500 $\mu \mathrm{m}$ meshes, were used to estimate zoo $_{1}{ }^{1}$ nkton size spectra. They were preserved in $4 \%$ formaldehyde buffered with sodium :traborate (0.5 g. $1^{-1}$, Newell and Newell, 1963). These formaldehyde-preserver $\mathrm{s}^{\prime} n_{1_{1}}$ les were used for the size spectrum analysis under a stereo microscope $\left(120 \mu \mathrm{n}_{1}\right.$, and in the ZooScan system $(300 \mu \mathrm{m}, 500 \mu \mathrm{m})$. For stereo microscope analyses (Ziss stemi $2000-$ C), the samples were split in $1 / 2$ to $1 / 256$ to obtain at least $300 \mathrm{Ol}_{\varepsilon}$ anisms per sample. The lengths and widths of 30 specimens for each taxonomic group were measured. If there were more than 30 individuals for each taxonomic group, they were counted for abundance analyses.

For ZooScan analyses, each zooplankton sample was separated into two fractions with a $1000 \mu \mathrm{m}$ mesh (Gorsky et al., 2010). Each size fraction was split by a Motoda splitter into $1 / 2$ to $1 / 64$ subsamples to obtain up to 2,000 objects in each scan. Large, rare organisms (> $1000 \mu \mathrm{m}$ size fraction) were scanned from $1 / 2$ to $1 / 8$ subsamples. For the more plentiful size fraction of small-sized organisms $(<1000 \mu \mathrm{m})$ a smaller 
subsample (1/4 to $1 / 64)$ was scanned. Subsamples were digitalized by the ZooScan system and processed with the ZooProcess software, which isolates each object into one vignette and generates a range of quantitative descriptors (size, grey level distribution and shape parameters) for each vignette. A semi-automatic approach was used to classify the vignettes into pre-established taxonomic groups, using the Plankton Identifier software (Gorsky et al., 2010). After classification, all results were manually validated to correct any misclassifications.

Equivalent spherical diameter (ESD), abundance and 1 lov lume were calculated for each organism. Zooplankton biovolume was estimated is th : ellipsoidal volume:

$$
\text { Biovolume }=\frac{4 \pi}{3}\left(\frac{\text { Major axis }}{2}\right)\left(\frac{\text { Minor axis }}{2}\right)^{2}
$$

where the major and minor axis $r \cdot a^{\prime}$ zooplankton organism were measured by the ZooScan or under the stereo micros 'ope. Zooplankton abundance and biovolume were classified into discrete size c. sses, based on their equivalent spherical diameter (ESD, calculated from the 2D rea,. Five ESD size classes $(0-I V)$ were defined $(0<200$ $\mu \mathrm{m}$; I $200-500 \mu \mathrm{m}$; II $50 \mathrm{c}-1000 \mu \mathrm{m}$; III $1000-2000 \mu \mathrm{m}$ and IV >2000 $\mu \mathrm{m}$ ).

\subsection{Stable isotopes}

Stable isotope analyses were conducted on particulate organic matter (POM) and on size-fractioned zooplankton samples that were obtained with a bongo net (additional subsurface hauls with $64 \mu \mathrm{m}, 120 \mu \mathrm{m}, 300 \mu \mathrm{m}$ and $500 \mu \mathrm{m}$ mesh). For each haul, all samples were pooled and sieved into five size fractions, using a multi-mesh array $(0<$ $200 \mu \mathrm{m}$; I: $200 \mu \mathrm{m}-500 \mu \mathrm{m}$; II: $500 \mu \mathrm{m}-1000 \mu \mathrm{m}$; III: $1000 \mu \mathrm{m}-2000 \mu \mathrm{m}$ and IV > 
$2000 \mu \mathrm{m})$. Each size fraction sample was packed into previously calcined aluminum envelopes, and kept frozen at $-20^{\circ} \mathrm{C}$.

In the laboratory, zooplankton samples were stored in Eppendorf micro tubes, and freeze dried during at least 24 hours. Once dried, each sample was homogenized to obtain a fine powder and weighed. In order to obtain unbiased values of $\delta^{13} \mathrm{C}$, part of the samples was separated to remove the carbonates $\left(\mathrm{CaCO}_{3}\right)$. These samples were acidified according to Fry (1988) by adding approximately $2 \mathrm{ml}$ of $\left(.5\right.$ mol. $1^{-1}$ hydrochloric acid $(\mathrm{HCl})$. After this procedure, samples were re-dried it $\left(9^{\circ} \mathrm{C}\right.$ for 24 hours and homogenized. Water samples collected at subsurface $(\sim 3 n)$ and at the depth of the chlorophyll a fluorescence maximum (Fmax) w re , sed to obtain POM samples by using pre-combusted GFF filters. POM samnies were acidified for extracting the carbonates. For this, the filters were exnos, $t$ to hydrochloric acid $(\mathrm{HCl})$ vapor. After 4 hours, the filters were left in an aluminu. ' covered box and dried at $40^{\circ} \mathrm{C}$ during $36 \mathrm{~h}$.

Samples were analyzed using an elemental analyzer (Thermo Scientific Flash EA 2000) coupled to an Isotope $\mathbf{k}$.tio Mass Spectrometer (Delta V+ mass) at the Pôle de Spectrométrie Océan (P!nuzá é, France). Results were expressed in standard $\delta$ notation based on internati na sta idards (Vienna Pee Dee Belemnite for $\delta^{13} \mathrm{C}$ and $\mathrm{N}_{2}$ in air for $\left.\delta^{15} \mathrm{~N}\right)$ following the -quation: $\delta \mathrm{X}=\left[\left(\mathrm{R}_{\text {sample }} / \mathrm{R}_{\text {standard }}\right)-1\right] \times 10^{3}$ (in \%o), where $\mathrm{R}$ is ${ }^{13} \mathrm{C} /{ }^{12} \mathrm{C}$ or ${ }^{15} \mathrm{~N} /{ }^{14} \mathrm{~N}$. The standard values were reproduced into a confidence limit: IAEA600 (certified values: $-27.77 \pm 0.04 \%$ for $\delta^{13} \mathrm{C}$ and $1.00 \pm 0.20 \%$ for $\delta^{15} \mathrm{~N}$; measured value: $-27.79 \pm 0.10 \%$ for $\delta^{13} \mathrm{C}$ and $1.09 \pm 0.06 \%$ for $\delta^{15} \mathrm{~N}$ ), IAEACH-6 (certified values: $-10.45 \pm 0.08 \%$ for $\delta^{13} \mathrm{C}$; measured value: $-10.43 \pm 0.08 \%$ for $\left.\delta^{13} \mathrm{C}\right)$, IAEA-N1 (certified values: $0.4 \pm 0.2 \%$ for $\delta^{15} \mathrm{~N}$; measured value: $0.45 \pm 0.10 \%$ o for $\delta^{15} \mathrm{~N}$ ) and IAEA-N-2 (certified values: $20.3 \pm 0.2 \%$ for $\delta^{15} \mathrm{~N}$; measured value: $20.24 \pm 0.12 \%$ for 
$\delta^{15} \mathrm{~N}$ ). One sample of a home standard (Thermo acetanilide) was analyzed for experimental precision, after every six samples.

\subsection{Trophic levels}

Trophic level (TL) was calculated based on $\delta^{15} \mathrm{~N}$ (Vander Zanden and Fetzer, 2007):

$$
T L=\frac{\left(\delta^{15} \mathrm{~N}_{\text {consumer }}-\delta^{15} \mathrm{~N}_{\text {baseli, }} \text { ? }\right)}{T E F} r \lambda
$$

where TEF is the trophic enrichment facto ard $\lambda$ is the trophic level of the baseline. Since isotopic values of phytoplanl tr n (TL1) are based on POM, which may be influenced by the co-occurrer e of detritus (Montoya et al., 2002) and microzooplankton in the water c.lumn (Post, 2002; Hunt et al., 2015; Yang et al., 2017), primary consumers were $\iota$ sf $d . \nu$ estimate the trophic level, once the they are less influenced by small-scale sp $\lambda_{1}{ }^{1}$ and temporal variation (Hunt et. al. 2015). Small-sized zooplankton is classicall: ust $\mathbb{d}$ as a baseline (TL 2; e.g., Fry and Quinones, 1994; Kline

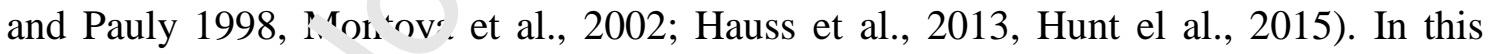
study, we assume the size-class I $(200-500 \mu \mathrm{m})$, to be closest to the primary consumer with TL 2. A TEF value of 3.2\% per TL was applied to estimate relative TLs for each zooplankton size class and sampling area (Post, 2002; Ménard et al., 2014). For comparison, TLs were also estimated using a TEF of $2.3 \%$ per TL, as given by Schwamborn and Giarrizzo (2015).

Differences in trophic level, stable isotopes composition, abundance and biovolume of zooplankton between areas (shelf, slope and oceanic islands) and between size 
classes were tested by non-parametric Kruskal-Wallis ANOVA $\left(p_{\text {crit }}=0.05\right)$, since these data displayed non-normality and heteroscedasticity. Post-hoc comparisons between pairs of samples were conducted with Dunn's test $\left(p_{\text {crit }}=0.05\right)($ Zar, 1996).

Ordinary least squares linear regression was used to investigate the linear relationship between $\log _{10}$-transformed average body size $(\mathrm{ESD}, \mu \mathrm{m})$ and trophic level (TL, estimated with $\mathrm{TEF}=3.2$ and 2.3 ). Body size $(\mathrm{ESD})$ was $\log 10$-transformed to obtain linear relationships for analysis and to improve hor 'escedasticity. The slope of this linear regression model was used to estimate the ave age predator/ prey size ratio (PPSR) and predator/ prey mass ratio (PPMR), using ti. fr llowing equations: PPSR = $10^{(1 / \text { slope })}$, if $\log _{10}$ is being used in the linear mor el ( Iunt et al., 2015), and PPMR = PPSR $^{3}$, assuming isometry and size-invariar.. tensity (Lins et al., 2019). PPSR and PPMR estimates obtained with TEF $=2<$ and 2.3 were then compared to previously published estimates. All data are available at: https://figshare.com/articles/datas_ı'?ociy_Size_Stable_Isotope_Figueiredo_et_al_Meta data_csv/12620807.

\section{Results}

\subsection{Hydrography}

Sea surface temperature was nearly homogeneous (median: $26.6^{\circ} \mathrm{C}$ ) over the whole study area. Surface salinity ranged from 36.1 to 36.6 , with higher values along the continental slope. The thermocline ranged between $\sim 80$ and $\sim 180 \mathrm{~m}$ in the slope area 
and $\sim 90$ and $\sim 130 \mathrm{~m}$ around oceanic islands (Assunção et al., in press). The chlorophyll $a$ fluorescence maximum was generally located at the upper limit of the thermocline.

\subsection{Zooplankton abundance and biovolume size structure composition}

A total of 15 taxonomic categories were identified: jellyfish, polychaetes, bivalves, gastropods, copepods, nauplii, euphausiids, mysids, decapods, salps, chaetognaths, appendicularians, fish eggs, fish larvae and "other zoopinkton" (composed by organisms with less than $3 \%$ abundance).

No significant differences were detected $b^{+}$ween zooplankton abundance, biovolume, and stable isotope composition $a^{t}$ huth oceanic island areas, Fernando de Noronha and Rocas Atoll (K-W-ANOVA, $p>0.05)$. Therefore, data from these two areas were pooled together as "oceaı c islands" for subsequent analyses. Samples obtained from the shelf and from the lope were analyzed separately, since they were different regarding several par ımı ${ }^{+}$rs, especially stable isotope composition (Fig. 5).

Abundance and biovol' $m \iota$ differed significantly between areas (K-W ANOVA, $p<$ 0.05; Table 1). Samp'es 'aken off oceanic islands had significantly lower abundances (mean: 6.0 ind. $\mathrm{m}^{-3} \pm 3 .{ }^{\text {; }}$; Table 2) than those obtained from the shelf and from the slope (means: 10.3 ind. $\mathrm{m}^{-3} \pm 6.5$ and 14.1 ind. $\mathrm{m}^{-3} \pm 16.8$, respectively). The slope presented significantly higher biovolume (mean: $11.0 \pm 15.4 \mathrm{~mm}^{3} \cdot \mathrm{m}^{-3}$ ) than oceanic islands (mean $3.3 \pm 1.5 \mathrm{~mm}^{3} \cdot \mathrm{m}^{-3}$ ) and the shelf (mean: $3.7 \pm 3.3 \mathrm{~mm}^{3} \cdot \mathrm{m}^{-3}$, Figure 2).

Zooplankton composition varied considerably among size classes (Figure 3). Copepoda was the most abundant group for the three size fractions ranging between 200 $\mu \mathrm{m}$ and $2000 \mu \mathrm{m}$ for all environments, and presented the largest contribution to biovolume. The taxonomic composition for the $>2000 \mu \mathrm{m}$ class showed a higher 
contribution of larger zooplankton organisms, such as Chaetognatha, Decapoda, and fish larvae, especially off oceanic islands (Figure 3).

\subsection{Stable isotope composition of zooplankton and POM}

Spatial patterns of stable isotope composition differed between POM and zooplankton. POM displayed consistently lower $\delta^{13} \mathrm{C}$ than zooplankton (Figure 4). Also, $\delta^{13} \mathrm{C}$ of POM showed a decreasing trend from the shelf tow in ${ }^{\text {ts }}$ offshore areas. $\delta^{13} \mathrm{C}$ of POM differed significantly between areas (Figure 5, Tahle 1, K-W ANOVA, p < 0.001 ), with higher $\delta^{13} \mathrm{C}$ values in shelf areas, follow $\mathrm{d}$ by the slope and oceanic islands (Figure 5). Conversely, zooplankton displayed an ' pposite pattern, with increasing values towards offshore areas (Figure 5, T $\lrcorner b^{\wedge} \mathrm{e} 2$ ). $\delta^{15} \mathrm{~N}$ and $\delta^{13} \mathrm{C}$ values of all zooplankton size classes differed sign; ${ }_{11}$ c atly between areas (Table 1, K-W ANOVA, p $<0.05$ ), with higher values off oce $\urcorner$ nic islands (Figure 5; Table SM 1) varying from $~ 22$ to $\sim 19 \%$ for $\delta^{13} \mathrm{C}$ and from $\sim 5$ to $\sim r, \%$, for $\delta^{15} \mathrm{~N}$.

POM had $\delta^{15} \mathrm{~N}$ values be veen 2.54 and 6.89\%o (mean at oceanic islands: $4.15 \%$, st. dev.: $1.2 \%$, mean at he helf: $4.00 \%$, st. dev.: $0.59 \%$, mean at the slope: $4.86 \%$, st. dev.: $1.24 \%$ o). Withi- he meso- and macrozooplankton, $\delta^{15} \mathrm{~N}$ generally increased with size, from the size fraction $<200$ to the size fraction $>2000 \mu \mathrm{m}$ (Figure 4). At the shelf, small-sized mesozooplankton (size fraction $200-500 \mu \mathrm{m}$ ) presented significantly more depleted values than the largest size (Table 2, $1000->2000 \mu \mathrm{m}, \mathrm{p}<0.05$, K-W ANOVA). At the slope, the $200-500 \mu \mathrm{m}$ size fraction showed significantly lower $\delta^{15} \mathrm{~N}$ values than the largest $(>2000 \mu \mathrm{m})$ size fraction (Table 2, p < 0.05, K-W ANOVA). 
$\delta^{13} \mathrm{C}$ values were significantly different between $>2000 \mu \mathrm{m}$ and $500-1000 \mu \mathrm{m}$ at the shelf (Figure 5, $p<0.01$, non-parametric ANOVA) and between $>2000 \mu \mathrm{m}$ and the other size fractions at oceanic islands (Table 2, $p<0.05$, non-parametric ANOVA).

\subsection{Trophic levels}

To estimate trophic levels (TL), according to other studies (e.g., Fry and Quinones, 1994; Kline and Pauly, 1998, Montoya et al., 2002; Haus, st al., 2013, Hunt el al., 2015) we used the mean $\delta^{15} \mathrm{~N}$ of the zooplankton samnlt. $\mathrm{i} \cdot$ the $200-500 \mu \mathrm{m}$ size class, from each region, as a baseline $(\mathrm{TL}=2)$, sincc this size fraction was consistently dominated by copepods, and the fact that this sı $r_{\text {a ass }}$ had the lowest $\delta^{15} \mathrm{~N}$ values. Oceanic areas (average baseline $\delta^{15} \mathrm{~N}=5.8 \%$ ) '.a $\mathrm{l}$ a higher baseline $\delta^{15} \mathrm{~N}$ than the shelf (average $=3.9 \%$ ) and the slope (ave agt $=. .1 \%$ ). In spite of differing baselines, the $\delta^{15} \mathrm{~N}$ data produced a very consist nt pattern of increase in trophic level with increasing size, in all regions (Figure 6). A $>\mathrm{s}$ ing $\mathrm{TEF}=3.2 \% \mathrm{TL}^{-1}$, the mean trophic level of the zooplankton was very sit $11 \iota^{r}$ with $\mathrm{TL}=2.2,2.3$ and 2.1 for shelf, slope and oceanic islands, respectively. $\mathrm{FC}^{-\mathrm{T}} \mathrm{TE} \overline{\mathrm{F}}=2.3 \% \mathrm{TL}^{-1}$, the mean were $\mathrm{TL}=2.3,2.5$ and 2.2 , in these sampling are: $:$, asn :ctively.

Linear regression analysis revealed a log-linear relationship between $\log _{10}$ (body size and TL (Figure 6). Linear models were always highly significant $(\mathrm{p}<0.001)$, for shelf, slope and oceanic islands areas. Slopes of the log (body size) vs TL relationships (Table 3) were not significantly different among areas (ANCOVA, $\mathrm{p}=0.07$ ). Overall average slope was $0.59 \pm 0.08 \mathrm{TL} \mu \mathrm{m}^{-1}$ with $\mathrm{TEF}=2.3$ and $0.42 \pm 0.59 \mathrm{TL} \mu \mathrm{m}^{-1}$ with $\mathrm{TEF}=3.2$. 
The choice of input TEF values only slightly changed the $\log _{10}$ (body size) $v s$ TL slopes, but this choice had a considerable effect on the estimates of predator/prey size ratio (PPSR) and predator/prey mass ratio (PPMR). For example, the estimate of PPMR at Oceanic Islands was 470 times lower when using $\mathrm{TEF}=2.3$ than when using $\mathrm{TEF}=$ 3.2. For TEF $=2.3$, PPSR was 49 , and PPMR was 121,547 . For TEF $=3.2$, these estimated were much higher, especially for PPMR. With TEF $=3.2$, PPSR was 240, and an extremely high PPMR estimate of 13,894,955.

\section{Discussion}

The present study revealed important ar ations in stable isotope ratios of zooplankton in the western tropical $f$ das tic that were conspicuously and significantly related to body size and geogra hical areas. Size-structured stable isotope analyses proved to be a useful approach to re: ribe the structure and functioning of the systems (Fry and Quiñones, 1994; M on vya et al., 2002; Lee et al., 2013; Hunt et al., 2015). It is the first study analyzing sizt classes and stable isotope composition of a zooplankton community carrie $\mathrm{i}^{\prime} \mathrm{o}^{+}$ir tropical shelf, slope and oceanic waters, providing several important new insigiı into these pelagic ecosystems. Also, our study showed that TEF choice has a profound effect on the resulting prey-predator mass and size ratios. Lower TEF values than those widely used, clearly lead to more realistic results for this zooplankton community. 
In the present study, zooplankton presented higher $\delta^{13} \mathrm{C}$ and $\delta^{15} \mathrm{~N}$ values off oceanic islands than in shelf and slope areas. Conversely, $\delta^{13} \mathrm{C}$ POM showed a clear coastaloffshore gradient, with ${ }^{13} \mathrm{C}$-enriched values at shelf areas, followed by slope and oceanic islands. Stable isotope composition of primary producers typically varies with spatiotemporal and physical features as a result of differences in biogeochemical processes that occur in each environment (Graham et al., 2010). Thus, $\delta^{13} \mathrm{C}$ values of POM followed an expected pattern, being more ${ }^{13} \mathrm{C}$-enriched in diatom-rich shelf environments than offshore, as observed in previous ctucies in the study area (Schwamborn et al., 1997; Schwamborn et al., 1999) ar ^ c'sewhere (Fry and Wainright, 1991).

An unexpected result was observed in re ${ }^{1-\text { rtion }}$ to zooplankton $\delta^{13} \mathrm{C}$ values, which were conspicuously and significantly diffe $\mathrm{e}_{\imath}, \eta t$ trom simultaneously obtained POM $\delta^{13} \mathrm{C}$ values. This discrepancy between POn, and zooplankton carbon isotope composition could be explained by two differe ... nhunomena. First, vertically migrating zooplankton may be feeding at depths tha an not represented by the sampling of POM. Second, zooplankton generally dis ${ }^{1}$ 'yy feeding selectivity (Sailley et al., 2015; Benedetti et al., 2016), which makes nelı isotope composition difficult to compare directly with POM values. POM encompa ses a highly variable mixture of a diversity of living organisms and non-living particles, among which only few may be selectively ingested by zooplankton (Lee et al., 2004). Our results indicate a selective use of $\delta^{13} \mathrm{C}$-rich food sources (e.g., diatoms) by zooplankton.

4.2 Spatial patterns of zooplankton abundance, biovolume, composition, size and stable isotope ratios 
We observed higher zooplankton abundance and biovolume over the slope than the shelf and in offshore areas (Figure 2). These results contradict the typical coastaloceanic gradient, previously found in the study area (Bueno et al., 2017; Campelo et al., 2018; Santana et al., 2018) and elsewhere (Dai et al., 2016; Giering et al., 2018). Indeed it is typically assumed that zooplankton abundance follows a continuous gradient with higher abundance nearshore (Neumann-Leitão et al., 2008; Marcolin et al., 2013; Leitão et al., 2019). This common pattern was mostly attributed to continental runoff, specifically the input of nutrients and organisms from large est. aries, and resuspension from shelf sediments (Schwamborn et al., 1999). Nicn nt inputs boost the primary production and may consequently generate a coastai ocean gradient of zooplankton density with higher abundance of organisms in cras. 1 environments than oligotrophic oceanic waters. The lower biomass values $\mathrm{o}_{\mathrm{L}} \mathrm{er}_{\mathrm{J}} \mathrm{ed}$ at the shelf than at the slope may occur because of a series of factors. Fir st, during the sampling period (September to October), there was a low continenta' influence (low river runoff during the dry season), low wind intensities (little reיisp ${ }^{\text {r }}$ sion from shelf sediments). Also, sampling was conducted off the main ref: ductive season for most coastal invertebrates (low larval inputs from coastal ecosvs ar is), which is generally from January to March, in the study area. In addition, r'v sical processes like eddies may allow a higher retention of plankton at the continental slope, leading to higher zooplankton biomass and densities (Franco et al., 2006; Katsuragawa et al., 2014). Our stations with highest abundance were located in a region close to continental slope, with mixed layer depth and upper thermocline shallower than expected for the season (Assunção et al., 2020). This leads to a shallowing of the nutricline and likely an increase in primary productivity sustaining the higher density of zooplankton. 
In this oligotrophic ecosystem we demonstrated the existence of zooplankton accumulation at the continental slope. The observed pattern also agrees with the finding that any direct estuarine influence in the study area is generally limited to approximately $10 \mathrm{~km}$ from the coast (Schwamborn et al., 1999, 2002). The shelf break is known to play an important role in transporting and retaining zooplankton (Genin, 2004; Zhu et al., 2009). Indeed, interactions between topography and currents aggregate zooplankton seaward of the shelf-break zone (e.g. Genin, 2004; Cotté and Simard, 2005; Swartzman et al., 2005). Also, the whole slope area, up to several $\mathrm{k}_{\mathrm{m}}$ off the shelf break, is characterized by strong turbulence and current shear se veen the base of the mixed layer and the upper thermocline that can transport $n_{\imath}$ trients from deep water masses upwards into the euphotic layer. This shear and turbu. ance is caused by the strong North Brazil Undercurrent (NBUC) that flows nc $\mathrm{rt}_{2} \cdot \mathrm{v} ? \mathrm{~d}$ ds along the shelf break (Stramma et al., 1995; Schott, et al., 2005). F.rtt srmore, significantly higher abundance and biovolume at the slope, as obse red in this study, may be due to small-scale mechanisms that were hitherto ign $\urcorner$ ¿d, e.g., upwelling at submarine canyons (Kämpf, 2007; Howattand and Aller, 201j), and zooplankton accumulations at fronts and eddies (Schwamborn et al., 2001, M Mps et al., 2015).

Zooplankton com sosition differed drastically between size-classes. Early life stages, such as invertebrate (probably mostly copepod) eggs, copepod nauplii, and gastropods dominated the smallest size class $(<200 \mu \mathrm{m})$, as found in many other regions, such as in the Mediterranean Sea (Bănaru et al., 2014). Similarly, in coastal areas of the Brazilian Northeast, Neumann Leitão et al. (2019) observed that nauplii and veliger larvae were the most frequent taxonomic groups in the microzooplankton (64 $120 \mu \mathrm{m}$ mesh net samples). Mesh size effects have already been documented in numerous zooplankton community studies (Tseng et al., 2011; Tosetto et al., 2019), 
which demonstrate that mesh size drastically affects the representation of the abundance, composition, and diversity of zooplankton communities.

Zooplankton composition in the size fraction from 500 to $2000 \mu \mathrm{m}$ is generally dominated by copepods (Mauchline, 1998), as observed by Neumann-Leitão et al. (2019) and Campelo et al. (2018) in coastal and oceanic waters of the western tropical Atlantic as well as in numerous other regions, such as in the south Atlantic (Boltovskoy, 1999), the Mediterranean (Bănaru et al., 2014; Espinasse $f i$ al., 2014), the subtropical north Pacific (Dai et al., 2016), the western tropical north I ac1 "c (Yang et al., 2016) and the eastern Atlantic (Marcolin et al., 2013).

Interestingly, in most cases, $\delta^{13} \mathrm{C}$ values $a_{1}{ }^{4}$ rot vary significantly with size, indicating that, in contrast to other studies (e g, : chwamborn and Giarrizzo, 2015), the primary carbon sources of zooplankt,$n 11$ thuse size classes were similar, and carbon isotopic fractionation was negligit?`.

Although most zooplankts.. si $i_{\llcorner}$fractions were dominated by copepods, the largest size fraction (> $2000 \mu \mathrm{m})$ sh 'wed the greatest richness in taxonomic groups, with many large-sized organisms ric: as fish larvae, euphausiids, mysids and many gelatinous organisms, such as s.'ps and chaetognaths. The higher abundance and biovolume of large-sized predators (e.g., fish larvae and chaetognaths) in the largest size class explains well why $\delta^{15} \mathrm{~N}$ and TL increased with size, showing a good consistency within and between our data sets.

Taxonomic compositions of both data sets (measured size classes and taxonomy $v s$ sieving and isotope analysis) were most likely very similar, since they were obtained concomitantly at each station. Also, the measured size has an obvious relation to the retention in sieves. Furthermore, the observed distributions of taxonomic groups within 
size groups were as expected (e.g., copepods being dominant in the smaller size fractions). In addition, with the approach we used, the taxonomic composition does not need to be absolutely identical in both datasets (i.e., only the size distribution has to be similar). Taxonomic information is presented here for illustration and to aid in interpreting the stable isotope results. Most importantly, the increase in $\delta^{15} \mathrm{~N}$ with size in this study was expected, since it agrees well with previous studies on zooplankton food webs in the southwestern subtropical Pacific (Hunt et al., 2015) and in the western tropical north Pacific (Yang et al., 2016).

\subsection{Body size as determinant of trophic level}

In previous trophic ecology studies, the iz r'asses chosen to determine the baseline differed widely between authors, e.g.. 1's - $250 \mu \mathrm{m}$ (Fry and Quinones, 1994), $200-$ $500 \mu \mathrm{m}$ (Hauss et al., 2013) or 250 - $500 \mu \mathrm{m}$ (Montoya et al., 2002). Assuming a sizebased food web structure, in o st... this size class was compose.' mainly by copepods, assumed to be mostly filter feeders and presented the smallost $5^{1} \mathrm{~N}$ values. Thus, their isotopic composition should be close to primary consume. ( 1 L2). In addition, copepods have better integrative properties than POM, since their turnover rate is much lower than most POM.

A positive relationship between $\delta^{15} \mathrm{~N}$ and size class within the zooplankton community was also observed in the Mediterranean Sea by Koppelman et al (2009) and Bănaru et al. (2014), except for the largest size class (> $2000 \mu \mathrm{m})$, which had lower $\delta^{15} \mathrm{~N}$ values, probably due to the contribution of low-TL salps, in contrast to the

dominance of high-TL chaetognaths in the present study. Their $\delta^{15} \mathrm{~N}$ data for sizefractioned zooplankton were generally very similar to the present study except for the 
largest zooplankton size class. A series of factors affect the trophic position and size of plankton. For example, variations in nutrient inputs regulate the size of primary producers (Kiørboe, 2008), thus strongly impacting species composition and size structure of herbivorous zooplankton and pelagic food webs.

\subsection{TEF choice and predator - prey size ratios}

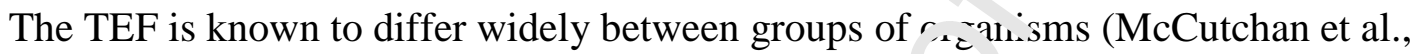
2003; Vanderklift and Ponsard, 2003). Schwamborn an $\downarrow$ Gi 7 rrizzo (2015) found a lower ecosystem-wide TEF value and much lower TEFs $f_{\text {רr }}$ ' 'igher TLs, which may support criticism of the use of fixed fractionation factors $\mathrm{He}_{2}$, we compared results for a TEF of 3.2 (Post, 2002; Ménard et al., 2014) an 1 L. ${ }^{2}$ (Schwamborn and Giarrizzo, 2015). A lower TEF in ecosystem-based studic , uch as in Schwamborn and Giarrizzo (2015),

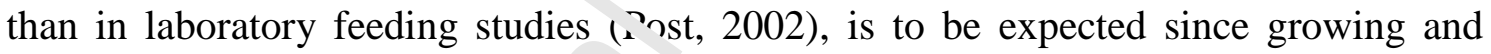
migrating animals in real eco , ste $\ldots$ s will be constantly shifting their diets and TLs. Thus, most organisms in na.' 'ral ecosystems will not attain full equilibrium with their current food source. In ast laboratory feeding experiments, only the final TEF (difference in $\operatorname{isot}_{\mathbf{r}}{ }^{\prime}$ ' composition between diet and consumer), under perfect equilibrium, is reported. TEFs that occur in natural ecosystems will not to represent this kind of situation. Thus, lower, ecosystem-based TEF values (e.g., 2.3\%o $\mathrm{TL}^{-1}$ ) may be more realistic for the use in zooplankton food web analyses (Schwamborn and Giarrizzo, 2015) than laboratory-derived TEF estimates. Our study showed that TEF choice has a huge influence on PPMR and that the use of TEF above 3 will lead to a gross overestimation of PPMR and subsequently underestimation of ecosystem trophic efficiency (TE). Hunt et al. (2015) obtained similar results for the meso-, 
macrozooplankton and micronekton communities in the subtropical Pacific. They also concluded that a TEF of 3.4\%o $\mathrm{TL}^{-1}$, that they used, likely overestimated PPMR and underestimated TE.

\subsection{PPMR as a key parameter for food webs and size spectra analyses}

Our PPMR calculations assume isometry (i.e., size-invariant shape) and sizeinvariant density, which are hardly fulfilled in nature. In the sunse, Lins et al. (2019) showed that on average, density is not significant ${ }^{1}$ y c fferent from 1 in tropical zooplankton samples, and that these relationships nat change with biomass. We are therefore confident that our basic assumptions are ufficiently well fulfilled for an assessment of PPMR. However we ackao, dge that the investigation of these important aspects deserves further eff, ${ }^{\text {trc }}$.

The large review by Hansen $A .1$. (1994) reported typical PPSR values of 18 to 50 for mesozooplankton. In our : udy, extremely high PPSR and PPMR estimates obtained with TEF $=3.2$ (Table 4), nay be considered unrealistic, since they were much higher than previously publi hea estimates (except for the slope area, where the lowest PPSR was observed). Conver ely, the application of $\mathrm{TEF}=2.3$ produced realistic estimates for shelf and slope data, and for the overall mean. The zooplankton communities around oceanic islands had very high PPSR, being above the Hansen et al. (1994) range, with both TEF values (TEF $=2.3$ and 3.2). This high PPSR is consistent with our observation of very abundant large organisms, such as fish larvae and gelatinous predators, in the waters around oceanic islands.

When using TEF $=3.2$, we would obtain an overall mean PPSR value of 240, which is far above any known estimates for mesozooplankton. Yet, when using TEF = 
2.3, our study indicates an overall mean PPSR value of 49, which is within the PPSR range given by Hansen et al. (1994). Similarly to the study of Hansen et al. (1994), we also used ESD to obtain PPSR estimates, so that both PPSR assessments seem well comparable, thus further strengthening the point for ESD as a standard measure of size in plankton research.

Community-wide PPSR above 1,000 should be considered extremely unlikely, such as those obtained with $\mathrm{TEF}=3.2$. This suggests that a reali ic $\mathrm{TEF}$ for the zooplankton community sampled in this study would rather be cl sse to 2.3 , as observed by Schwamborn and Giarrizzo (2015). Since there are $s^{t} i_{i}^{\prime}$ ve y few studies available that attempt to estimate PPMR and PPSR based or stc ble isotopes and size-structured zooplankton sampling, our results may be user is a baseline for future studies.

\section{Acknowledgements}

We would like to thank the Natioı al Council for Scientific and Technological Development (CNPq, PhD fellowships aw ' 'de' to the first author), the ABRACOS project (Acoustics along the Brazilian Coast), fur uc ' by Institut de Recherche pour le Développement, IRD), the crew of R/V ANTEA, the Braz. 'ian National Institute of Science and Technology in Tropical Marine Environments (INCT-AmbTropic, CNPQ/CAPES/FAPESB) for the logistic and financial support, the Laboratoire des sciences de l'environnement Marin (LEMAR) for the stable isotope analyses support. RS and AB received support from the European Union's Horizon 2020 research and innovation program under Grant Agreement No 734271. Many thanks to the Brazilian Navy for permit (Portaria N ${ }^{\circ}$ 178/EMA, 08/09/2015) and to the Brazilian Ministry of the Environment MMA / ICMBio for SISBIO permit no47270-4. This study is a contribution to the LMI TAPIOCA, the SMAC project (CAPES/COFECUB n 88881.142689/2017-01) and to the PADDLE project, which has received funding from the European Union's Horizon 2020 
research and innovation program under grant agreement No 73427. Many thanks to Simone M.

A. Lira, Xiomara F.G. Díaz, Pedro A.M.C. Melo and Lucas Figueiredo, for the support in sampling during the cruise.

\section{Supplementary material}

Table MS1. Zooplankton size classes stable isotope composition between the three areas $\delta^{13} \mathrm{C}$ and $\delta^{15} \mathrm{~N}$ minimum, maximum mean and standard deviation values.

\begin{tabular}{|c|c|c|c|c|c|c|c|c|}
\hline Size Classes & $\begin{array}{l}\delta^{13} \mathrm{C} \\
\mathrm{Min}\end{array}$ & $\begin{array}{l}\delta^{13} \mathrm{C} \\
\mathrm{Max}\end{array}$ & $\begin{array}{c}\delta^{13} \mathrm{C} \\
\text { Mean }\end{array}$ & $\begin{array}{c}\delta^{13} \mathrm{C} \\
\mathrm{sd}\end{array}$ & $\begin{array}{r}10 \\
1.0 \\
N_{i+1}^{10}\end{array}$ & $\begin{array}{l}\delta^{15} \mathrm{~N} \\
\mathrm{Max}\end{array}$ & $\begin{array}{c}\delta^{15} \mathrm{~N} \\
\text { Mean }\end{array}$ & $\begin{array}{c}\delta^{15} \mathrm{~N} \\
\mathrm{sd}\end{array}$ \\
\hline & \multicolumn{8}{|c|}{ Com t } \\
\hline$<200 \mu \mathrm{m}$ & -23.23 & -20.92 & -22.08 & 1.63 & 3.17 & 4.20 & 3.69 & 0.73 \\
\hline $200-500 \mu \mathrm{m}$ & -21.49 & -20.20 & -21.08 & 038 & 2.87 & 5.09 & 3.91 & 0.69 \\
\hline $500-1000 \mu \mathrm{m}$ & -21.39 & -20.32 & -20.72 & 932 & 3.88 & 6.12 & 4.59 & 0.79 \\
\hline $1000-2000 \mu \mathrm{m}$ & -21.87 & -20.43 & -21.07 & 0.57 & 4.43 & 6.42 & 5.05 & 0.63 \\
\hline \multirow[t]{2}{*}{$>2000 \mu \mathrm{m}$} & -22.17 & -20.79 & $-21+6$ & 0.43 & 4.51 & 6.17 & 5.08 & 0.52 \\
\hline & \multicolumn{8}{|c|}{ Slope } \\
\hline$<200 \mu \mathrm{m}$ & -21.79 & -21.71 & -2.74 & 0.05 & 4.40 & 5.39 & 4.92 & 0.50 \\
\hline $200-500 \mu \mathrm{m}$ & -22.39 & -20.48 & $-2,16$ & 0.63 & 1.07 & 4.03 & 3.06 & 0.94 \\
\hline $500-1000 \mu \mathrm{m}$ & -21.76 & -20.05 & -2.14 & 0.48 & 2.24 & 5.25 & 4.03 & 0.92 \\
\hline $1000-2000 \mu \mathrm{m}$ & -23.21 & -20.44 & -21.58 & 0.86 & 2.54 & 5.26 & 4.13 & 0.79 \\
\hline \multirow[t]{2}{*}{$>2000 \mu \mathrm{m}$} & -22.76 & $-20 ?$ & -21.75 & 0.66 & 3.28 & 6.92 & 5.04 & 1.09 \\
\hline & \multicolumn{8}{|c|}{ Oceanic Islands } \\
\hline$<200 \mu \mathrm{m}$ & -21.95 & $-\angle 223$ & -20.94 & 0.55 & 5.10 & 7.52 & 5.99 & 0.60 \\
\hline $200-500 \mu \mathrm{m}$ & -21.02 & 20.29 & -20.64 & 0.26 & 5.07 & 6.84 & 5.79 & 0.52 \\
\hline $500-1000 \mu \mathrm{m}$ & -21.75 & 19.96 & -20.72 & 0.43 & 5.54 & 6.91 & 6.00 & 0.38 \\
\hline $1000-2000 \mu \mathrm{m}$ & -21.22 & -20.24 & -20.62 & 0.26 & 5.88 & 8.25 & 6.52 & 0.62 \\
\hline$>2000 \mu \mathrm{m}$ & -20.65 & -18.69 & -20.02 & 0.50 & 5.88 & 8.89 & 6.67 & 0.68 \\
\hline
\end{tabular}

\section{References}

Assunção, R.V., Silva, A.C., Roy, A., Bourlès, B., Silva, C.H., Ternon, J.-F., Bertrand, A., 2020. 3D characterisation of the thermohaline structure in the southwestern tropical Atlantic derived from functional data analysis of in situ profiles. Prog. Oceanogr., in press. 
Bănaru, D., Carlotti, F., Barani, A., Grégori, G., Neffati, N., Harmelin-Vivien, M., 2014. Seasonal variation of stable isotope ratios of size-fractionated zooplankton in the Bay of Marseille (NW Mediterranean Sea). J. Plankton Res. 36, 145-156.

Benedetti, F., Gasparini, S., Ayata, S.D., 2015.Identifying copepod functional groups from species functional traits. J. Plankton Res. 38, 159-166.

Bertrand, A., 2015. ABRACOS cruise, RV Antea, https://doi.org/10.17600/15005600

Bode, A., Alvarez-Ossorio, M.T., Cunha, M. E., Garrido, S, Delıteiro, J.B., Porteiro, C., Valdes, L.,Varela, M., 2007. Stable nitrogen isotope stu 'ies of the pelagic food web on the Atlantic shelf of the Iberian Peninsula. Prog $\mathbf{n}_{c c} \cdot$ nogr. $74,115-131$.

Boltovskoy, D., 1999. South Atlantic zooplan's.. n. Leiden: Backhuys Publishers.

Brandão, M.C., Koettker, A.G., Freire, A. ;., 2013. Abundance and composition of decapod larvae at Saint Paul's Rocn - (equatorial Atlantic).J. Mar. Ecol. 34, 171-185.

Boltovskoy, D. (ed.) 1999. Sor u. Auantic Zooplankton. Backhuys Publishers, Leiden.

Bueno, M., Alberto, S.F., Ca "valho, R., Costa, T.M., Ciotti, A.M., Christofoletti, R.A., 2017. Plankton in wat ars c djacent to the Laje de Santos state marine conservation park, Brazil: spatio-tempo a1 distribution surveys. Braz. J. Oceanogr. 65, 564-575

Campelo, R.P.S., Diaz, X.F.G., Santos, G., Melo, P.A.M.C., Melo Junior, M., Figueiredo, L.G.P., et al., 2018. Small-scale distribution of the mesozooplankton in a tropical insular system. Braz. J. Oceanogr. 66, 15-29.

Cohen, J.E, Pimm, S.L, Yodzis P., Saldaña, J., 1993. Body sizes of animal predators and animal prey in food webs. J. Anim. Ecol. 62, 67-78. 
Cotté, C., Simard, Y., 2005. Formation of dense krill patches under tidal forcing at whale feeding hot spots in the St. Lawrence Estuary. Mar. Ecol. Prog. Ser. 288, 199210.

Dai, L., Li, C., Yang, G., Sun, X., 2016. Zooplankton abundance, biovolume and size spectra at western boundary currents in the subtropical North Pacific during winter 2012. J. Mar. Syst. 155, 73-83.

Diaz, X.F.G., Gusmão, L.M.O., Neumann-Leitão, S., 2009.B.` diversidade e dinâmica espaço- temporal do zooplâcton. In: Viana, D.L., Hazin, F.ı' V., Souza, M.A.C. 2009. O arquipélago de São Pedro e São Paulo: 10 anos de Es+ içâu científica. Brasília: SECIRM, 128-137.

Espinasse, B., Harmelin-Vivien, M., Tiano, Mı., suilloux, L., Carlotti, F., 2014. Patterns of variations in $\mathrm{C}$ and $\mathrm{N}$ stable isotope ' $\mathrm{g}^{\prime} \mathrm{os}$ in size-fractionated zooplankton in the Gulf of Lion, NW Mediterranean Sea. I. Plankton Res. 36, 1204-1215.

Franco, B.C., Muelbert, J.H., Mata, M.M., 2006. Mesoscale physical processes and the distribution and compositio` oi ichthyoplankton on the Southern Brazilian shelf break. Fish Oceanogr. 15, 37-43.

Fry, B., Wainright, S.c., 1991. Diatom sources of 13C-rich carbon in marine food webs. Mar. Ecol. Progr.Ser.76, 149 - 157.

Fry, B., 1988. Food web structure on Georges Bank from stable C, N, and S isotopic compositions. Limn. Oceanogr. 33, 1182-1190.

Fry, B., 2006. Stable isotope ecology. New York: Springer. 
Fry, B., Quinones, R.B., 1994. Biomass spectra and stable isotope indicators of trophic level in zooplankton of the northwest Atlantic. Mar. Ecol. Prog. Ser. 112, 201-204.

Genin, A., 2004. Bio-physical coupling in the formation of zooplankton and fish aggregations over abrupt topographies. J. Mar. Syst. 50, 3-20.

Giering, S.L., Wells, S.R., Mayers, K.M., Schuster, H., Cornwell, L., Fileman, E.S., Atkinson, A., Cool, K.B., Preece, C., Mayor, D.J., 2018. Seasonal variation of zooplankton community structure and trophic position in the _eltic Sea: a stable isotope and biovolume spectrum approach. Prog. Oceanogr. 177. $1 \iota^{10}+3$.

Gorsky, G., Ohman, M.D., Picheral, M., Gasparini c ¿`emmann, L., Romagnan, J.B., Cawood, A., Pesant, S., Garcia-Comas, C., Prejge , F., 2010. Digital zooplankton image analysis using the ZooScan integrated syste n. : : lankton Res. 32, 285-303.

Gove, J.M., McManus, M.A., Neuheimeı, A.B., Polovina, J.J., Drazen, J.C., Smith, C.R., Merrified, M.A., Friiedlane, i. K., Ehses, A.S., Young, A.W., Dillon, A.K., Williams, G.J., 2016.Near-isl^ 1d viological hotspots in barren ocean basins.Nat. Commun.7, 1058.

Graham, B.S., Koci I I Newsome, S.D., Mcmahon, K.W., Aurioles, D., 2010. "Using isoscapes to trace the movements and foraging behavior of top predators in oceanic ecosystems," in Isoscapes: Understanding Movement, Pattern, and Process on Earth Through Isotope Mapping, eds J. B. West, G. J. Bowen, T. E. Dawson, and K. P. Tu (Dordrecht: Springer), 299-318.

Guidi, L., Chaffron, S., Bittner, L., Eveillard, D., Larhlimi, A., Roux, S., Darzi, Y., Audic, S., Berline, L., Brum, J.R., Coelho, L.P., Espinoza, J.C.I., Malviya, S., Sunagawa, S., Dimier, C., Kandels-Lewis, S., Picheral, M., Poulain, J., Searson, S., 
Coordinators, T.O.C., Stemmann, L., Not, F., Hingamp, P., Speich, S., Follows, M., Karp-Boss, L., Boss, E., Ogata, H., Pesant, S., Weissenbach, J., Wincker, P., Acinas, S.G., Bork, P., de Vargas, C., Iudicone, D., Sullivan, M.B., Raes, J., Karsenti, E., Bowler, C., Gorsky, G., 2016. Plankton networks driving carbon export in the oligotrophic ocean. Nature. 24, 165-180.

Hansen, B., Bjornsen, P.K., Hansen, P.J., 1994. The size ratio between planktonic predators and their prey. Limn. Oceanogr. 39, 395-403.

Hauss, H., Franz, J.M., Hansen, T., Struck, U., Sommer, I., 90 13. Relative inputs of upwelled and atmospheric nitrogen to the eastern trop cal ivorth Atlantic food web: Spatial distribution of $\delta^{15} \mathrm{~N}$ in mesozooplankton an ${ }^{1}$ re ation to dissolved nutrient dynamics. Deep Sea Res. Part I: Oceanogr. R æs F æpers.75, 135-145.

Howatt, T.M., \& Allen, S.E., 2013. $\operatorname{In}_{\iota_{\perp}}{ }^{\nexists \jmath}$ t of the continental shelf slope on upwelling

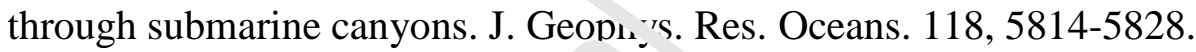

Hunt, B.P., Allain, V., Menkè` C., Lorrain, A., Graham, B., Rodier, M., Pagano, M. Carlotti, F., 2015. A couple. 'sluble isotope-size spectrum approach to understanding pelagic food-web dyn ımı s: a case study from the southwest sub-tropical Pacific. Deep Sea Res. Part II Top. S ud. Oceanogr. 113, 208-224.

Jennings, S., Oliveira, J.A.D., Warr, K.J., 2007.Measurement of body size and abundance in tests of macroecological and food web theory. J. Anim. Eco. 76, 72-82.

Jennings, S., Warr, K.J., Mackinson, S., 2002. Use of size-based production and stable isotope analyses to predict trophic transfer efficiencies and predator-prey body mass ratios in food webs. Mar. Ecol. Prog. Ser. 240, 11-20. 
Kämpf, J., 2007. On the magnitude of upwelling fluxes in shelf-break canyons. Cont. Shelf Res. 27, 2211-2223.

Katsuragawa M., Dias J.F., Harari, J., Namiki, C., Zani-Teixeira, M.L., 2014. Patterns in larval fish assemblages under the influence of the Brazil current. Cont. Shelf Res. 89, 103-117.

Kiørboe, T., 2008. Optimal swimming strategies in mate-searching pelagic copepods. Oecologia. 155, 179-192.

Kline, T.C., Pauly, D., 1998. Cross-validation of trophi le vel estimates from a massbalance model of Prince William Sound using ${ }^{15} \mathrm{~N} /{ }^{14} \mathrm{~N}$ i' 'ta. p. 693-702. In: T.J. Quinn II, F. Funk. Heifetz, J.N., Ianelli, J.E., Powers, J.F., S.hweigert, P.J, Sullivan, C.-I., Zhang (eds.) Proceedings of the Internation 1 N $_{y}$. Models. Alaska Sea Grant College Prı „r ‘m Report No. 98-01.

Koppelmann, R., Böttger-Schnac',, . Möbius, J., Weikert, H., 2009. Trophic relationships of zooplankton $\mathrm{i}^{*}$ the zastern Mediterranean based on stable isotope measurements. J. Plankton Pes. 31, 669-686.

Lee, C., Wakeham, S., ^r.ısti, C., 2004. Particulate organic matter in the sea: the composition conundrum. AMBIO, 33, 565-576.

Lins Silva, N., Marcolin, C. R., Schwamborn, R., 2019. Using image analysis to assess the contributions of plankton and particles to tropical coastal ecosystems. Est.Coast. Shelf Sci. 219, 252-261.

Lira, S.M.D.A., Teixeira, I.D.Á., Lima, C.D.M.D., Santos, G.D.S., Leitão, S.N., Schwamborn, R., 2014. Spatial and nycthemeral distribution of the zooneuston off Fernando de Noronha, Brazil. Braz. J. Oceanog. 62, 35-45. 
Maps, F., Plourde, S., McQuinn, I.H., St-Onge-Drouin, S., Lavoie, D., Chassé, J.,

Lesage, V., 2015. Linking acoustics and finite-time L yapunov exponents reveals areas and mechanisms of krill aggregation within the Gulf of St. Lawrence, eastern Canada. Limn. Oceanogr. 60, 1965-1975.

Marcolin, C.R., Schultes, S., Jackson, G.A., Lopes, R.M., 2013. Plankton and seston size spectra estimated by the LOPC and ZooScan in the Abrolhos Bank ecosystem (SE Atlantic). Cont. Shelf Res. 70, 74-87.

Mauchline, J., 1998. The biology of calanoid copepods. Aa ar es in marine biology, Academic Press. 33.

McConnaughey, T., McRoy, C.P., 1979.Food-wer str. carbon isotopes in the Bering Sea. Mar. Bic i. .2, 257-262.

McCutchan Jr, J.H., Lewis Jr, W.M., Keı. Jall, C., McGrath, C.C., 2003. Variation in trophic shift for stable isotope rat' os of carbon, nitrogen, and sulfur. Oikos, 102, 378390.

Ménard, F., Benivary, H.?., lodin, N., Coffineau, N., Le Loc'h, F., Mison, T., Richard, P. Potier, M., 2014. Staile isotope patterns in micronekton from the Mozambique Channel. Deep Sea Kes. Part II: Trop. Stud. Stud. Oceanogr. 100, 153-163.

Miller, T.W., Brodeur, R.D., Rau, H.G., 2008. Carbon stable isotopes reveal relative contribution of shelf-slope production to the Northern California Current pelagic community. Limnol. Oceanogr. 53, 1493-1503.

Minagawa, M., Wada, E., 1984. Stepwise enrichment of ${ }^{15} \mathrm{~N}$ along food chains: further evidence and the relation between $\delta^{15} \mathrm{~N}$ and animal age. Geochim. Cosmochim. Acta. 48, 1135-1140. 
Mompeán, C., Bode, A., Benítez-Barrios, V.M., Domínguez-Yanes, J.F., Escánez, J., Fraile-Nuez, E., 2013. Spatial patterns of plankton biomass and stable isotopes reflect the influence of the nitrogen-fixer Trichodesmium along the subtropical North Atlantic. J. Plankton Res. 35, 513-525.

Montoya, J.P., Carpenter, E.J., Capone, D.G., 2002. Nitrogen fixation and nitrogen isotope abundances in zooplankton of the oligotrophic North Atlantic. Limnol. Oceanogr. 47, 1617-1628.

Neumann-Leitão, S., Gusmão, L.M.O., Silva, T.D.E.; Nasc ne.ıto-Vieira, D.A., Silva, A.P., 1999. Mesozooplankton biomass and diversity " coastal and oceanic waters off North-Eastern Brazil. Arch. Fish. Mar. Res. 47, 15 $1 f 5$.

Neumann-Leitao, S., Melo Junior, M., Nets, 1., $\Gamma_{1}$ gueiredo, F., Silva, A.P., Díaz, X.F.G., et al., 2019. Connectivity betw ae. coastal and oceanic zooplankton from Rio Grande do Norte in the tropical weste $\eta$ Atlantic. Front. Mar. Sci. 6, 287.

Neumann-Leitão, S., Sant'ann` E.i.1.E., Gusmão, L.M.D.O., Nascimento-Vieira, D.A., Paranaguá, M.N., Schwamı `rı, R., 2008. Diversity and distribution of the mesozooplankton in t'ie ti pical Southwestern Atlantic. J. Plankton Res. 30, 795-805.

Newell, G.E., Newelı, R.C., 1963. Marine plankton: a practical guide. London: Hutchlson Educational

Petchey, O.L., Beckerman, A.P., Riede, J.O., Warren, P.H., 2008. Size, foraging, and food web structure. Proc. Natl Acad. Sci. USA. 105, 4191-4196.

Platt, T., Denman, K., 1977. Organization in the pelagic ecosystem. Helgolander Wiss. Meeresunters. 30, 575-581 
Post, D.M., 2002.Using stable isotopes to estimate trophic position: models, methods, and assumptions. Ecology, 83, 703-718.

Saiz, E., Calbet, A., Atienza, D., Alcaraz, M., 2007. Feeding and production of zooplankton in the Catalan Sea (NW Mediterranean). Prog. Oceanogr. 74, 313-328.

Sailley, S.F., Polimene, L., Mitra, A., Atkinson, A., Allen, J.I., 2015. Impact of zooplankton food selectivity on plankton dynamics and nutrient cycling. J. Plankton Res. 37, 519-529.

Santana, C.S.D., Schwamborn, R., Neumann-Leitão, S. Mı ntes, M.D.J.F., Lira, S.M.D.A., 2018.Spatio-temporal variation of plank $\sim^{+n} 1 \iota$ decapods along the leeward coast of the Fernando de Noronha archipelago, Br ^ziı. Braz. J. Oceanogr. 66, 1-14.

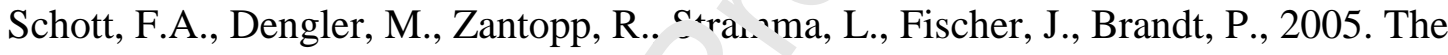
Shallow and Deep Western Boundary $\mathrm{C}_{1} \cdot{ }^{\circ}$ llation of the South Atlantic at $5^{\circ}-11^{\circ} \mathrm{S}$. J. Phys. Oceanogr. 35, 2031-2053.

Schwamborn, R, Neumann-I elı̃n, S., Silva, T.A., Silva, A.P., Saint-Paul, U., 2001. Distribution and dispersa' of ' ' ecapod crustacean larvae and other zooplankton in the Itamaracá estuarinı $\mathbf{V}_{\llcorner}^{+}{ }^{+}{ }_{\perp}$, Brazil. Trop. Oceanogr. 29, 1-18.

Schwamborn, R., Ekau, W., Voss, M., Saint-Paul, U., 1999. Stable isotope composition of particulate organic matter and zooplankton in northeast Brazilian shelf waters. Arc. Fish. Mar. Res. 47, 201-210.

Schwamborn, R., Giarrizzo, T., 2015. Stable isotope discrimination by consumers in a tropical mangrove food web: How important are variations in $\mathrm{C} / \mathrm{N}$ ratio? Estuar. Coast. $38,813-825$. 
Schwamborn, R., Voss, M., Ekau, W., Saint-Paul, U., 2002. How important are mangroves as carbon sources for decapod crustacean larvae in a tropical estuary? Mar. Ecol. Prog. Ser. 229, 195-205.

Stramma, L., Fischer, J., Reppin, J., 1995. The North Brazil Undercurrent. Deep Sea Res. Part I: Oceanogr. Res. Papers. 42, 773-795.

Swartzman, G., Hickey, B., Kosro, M., Wilson, C., 2005. Poleward and equatorward currents in the Pacific Eastern Boundary Current in summer _'95 and 1998 and their relationship to the distribution of euphausiids. Deep Sea R€. Part II Top. Stud. Oceanogr. 52, 73-88.

Tosetto, E.G., Neumann-Leitão, S., Júnior, M.N., 201? Sampling planktonic cnidarians with paired nets: Implications of $\mathrm{m}^{-\boldsymbol{h}}$ size on community structure and abundance. Estuar., Coast. Shelf Scieı. ?'20, 48-53.

Tseng, L.C., Dahms, H.U., Hung J. Chen, Q.C., Hwang, J.S., 2011. Can different mesh sizes affect the results $\mathrm{c}^{\dagger}$ cop pod community studies? J. Exp. Mar. Biol. Ecol. $398,47-55$.

Vander Zanden, J.ı . . Tot.er,W.W., 2007. Global patterns of aquatic food chain length. Oikos.116, 1378-13ðъ.

Vanderklift, M.A., Ponsard, S., 2003. Sources of variation in consumer - diet $\delta 15 \mathrm{~N}$ enrichment: a meta- analysis. Oecologia 136, 169-182.

Wang, S.W., Budge, S.M., Gradinger, R.R., Iken, K., Wooller, M.J., 2014. Fatty acid and stable isotope characteristics of sea ice and pelagic particulate organic matter in the Bering Sea: tools for estimating sea ice algal contribution to Arctic food web production. Oecologia. 174, 699-712. 
Yang, G., Li, C., Guilini, K., Wang, X., Wang, Y., 2017. Regional patterns of $\delta^{13} \mathrm{C}$ and

$\delta^{15} \mathrm{~N}$ stable isotopes of size-fractionated zooplankton in the western tropical North

Pacific Ocean. Deep Sea Res. Part I: Oceanogr. Res. Papers. 120, 39-47.

Yang, G., Li, C.L., Guilini, K., Peng, Q., Wang, Y., Zhang, Y., Zhang, Y., 2016.

Feeding strategies of four dominant copepod species in Prydz Bay, Antarctica: insights from a combined fatty acid biomarker and stable isotopic approach. Deep Sea Res. Part I: Oceanogr. Res. Papers. 114, 55-63.

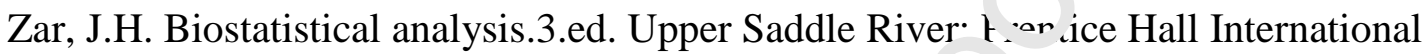
Editions, 1996. p. 662.

Zhu, Y., Tande, K., Zhou, M., 2009. Mesoscale $\mathrm{p}^{r} . y s ı$ al processes and zooplankton transport-retention in the northern Norwegi an $\Sigma^{h}$ _lf region. Deep Sea Res. Part II Top. Stud. Oceanogr. 56, 1922-1933.

\section{1y. res and tables legends}

Figure 1.Sampling ${ }^{+} \mathrm{at} \mathbf{t}_{1} \mathrm{n}$ in the tropical Atlantic off northeastern Brazil, in September and October 2015.Color coas s indicate sampling stations on the continental shelf, at the slope, and off two oceanic islands ( $\mathrm{F}_{1}$. . Fernando de Noronha Archipelago and RA: Rocas Atoll).

Figure 2. Mean ( \pm standard deviations) zooplankton abundance and biovolume between continental shelf, slope and oceanic islands in the tropical Atlantic off northeastern Brazil. All values shown represent the sum of all size classes

Figure 3. Relative abundance and biovolume of zooplankton classified within four size classes (0-IV). I: 200 - $500 \mu \mathrm{m}$; II: 500 - $1000 \mu \mathrm{m}$; III: 1000 - $2000 \mu \mathrm{m}$ and IV: > $2000 \mu \mathrm{m}$. Samples were collected on the continental shelf, at the slope and off oceanic islands in the tropical Atlantic off northeastern Brazil. 
Figure 4. Mean $\delta^{13} \mathrm{C}$ and $\delta^{15} \mathrm{~N}$ ( \pm standard deviation) of particulate organic matter (POM) and size-fractionated zooplankton sampled on the continental shelf, at the slope and off oceanic islands in the tropical Atlantic off northeastern Brazil.

Figure 5: $\delta^{13} \mathrm{C}$ and $\delta^{15} \mathrm{~N}$ (in \%o) of particulate organic matter (POM) and zooplankton size fractions $(0,<200 \mu \mathrm{m}$; I: $200-500 \mu \mathrm{m}$; II: $500-1000 \mu \mathrm{m}$; III: $1000-2000 \mu \mathrm{m}$; IV > 2000 $\mu \mathrm{m})$ on the shelf, at the slope and off oceanic islands in the western tropical Atlantic.

Figure 6: Trophic level (TL) and $\log _{10}$ (mean ESD size, $\mu \mathrm{m}$ ) for zach zooplankton size class in the western tropical Atlantic. TL was calculated from $\delta^{15} \mathrm{~N}$, asun ming a trophic enrichment factor of 3.2 and 2.3\% $\mathrm{TL}^{-1}$. Grey area: $95 \%$ confidence en $\mathrm{el}_{1}$ e for the linear regression slope.

Table 1. Results of Kruskal-Wallis ANOVA (p-values) an`' Dunn's post-hoc test on Particulate Organic Matter (POM), zooplankton $\delta^{13} \mathrm{C}, \delta^{15} \mathrm{~N}$, abunqa ce and biovolume according to local (S: Shelf; SB: Slope and OI: Oceanic Islands) an : ze classes $(0:<200 \mu \mathrm{m}$; I: $200-500 \mu \mathrm{m}$; II: $500-1000 \mu \mathrm{m}$; III: $1000-2000 \mu \mathrm{m}$, IV > 2x $\boldsymbol{x}^{n}$ r.1). n.s: not significant (i.e., $p>0.05$ ).

Table 2. Results of Kruskal -Wallis ' NOVA and Dunns's post-hoc test with zooplankton $\delta^{13} \mathrm{C}$ and $\delta^{15} \mathrm{~N}$, classified into five size clarras (? < $200 \mu \mathrm{m}$; I: $200-500 \mu \mathrm{m}$; II: $500-1000 \mu \mathrm{m}$; III: $1000-2000 \mu \mathrm{m}$; IV > $2000 \mu \mathrm{m}$ ) for e ch area: Continental Shelf, Slope and Oceanic islands.

Table 3. Slope values of $\imath$ ophic level (TL) vs body size (ESD, $\mu \mathrm{m})$, testing two different trophic enrichme: factors $(\mathrm{TEF}=3.2$ and 2.3$)$, for each area $( \pm$ standard errors).

Table 4. Predator/prey mass ratio (PPMR) and predator/prey size ratio (PPSR) testing two different trophic enrichment factors $(\mathrm{TEF}=3.2$ and 2.3$)$, for each area.

\section{Supplementary material}

Table MS1. Zooplankton size classes stable isotope composition between the three areas $\delta^{13} \mathrm{C}$ and $\delta^{15} \mathrm{~N}$ minimum, maximum mean and standard deviation values. 
Tables

Table 1.

\begin{tabular}{|c|c|c|c|}
\hline Response variable & Factor & $P$ & Post hoc \\
\hline \multirow{2}{*}{$\delta^{13} \mathrm{C}$ Zooplankton } & Area & $<0.001$ & $\mathrm{OI}>\mathrm{S}>\mathrm{SB}$ \\
\hline & Size class & n.s. & n.s \\
\hline \multirow{2}{*}{$\delta^{15} \mathrm{~N}$ Zooplankton } & Area & $<0.001$ & $\mathrm{OI}>\mathrm{S}=\mathrm{SB}$ \\
\hline & Size class & $<0.001$ & $\mathrm{I}>0=\mathrm{III}=\mathrm{IV} ; \mathrm{I}>\mathrm{IV}$ \\
\hline$\delta^{13} \mathrm{C} \mathrm{POM}$ & Area & $<0.001$ & $\tilde{n}>\mathrm{SB}>\mathrm{OI}$ \\
\hline$\delta^{15} \mathrm{~N}$ POM & Area & n.s. & n.s \\
\hline Abundance & Area & $<0.0$ & $\mathrm{SB}=\mathrm{S}>\mathrm{OI}$ \\
\hline Biovolume & Area & $<\prime .0>$ & $\mathrm{S}=\mathrm{SB} ; \mathrm{S}=\mathrm{OI} ; \mathrm{SB}>\mathrm{OI}$ \\
\hline
\end{tabular}

Table 2. Results of Kruskal -Wallis $\therefore \mathrm{NU}^{\top} \mathrm{A}$ and Dunns's post-hoc test with zooplankton $\delta^{13} \mathrm{C}$ and $\delta^{15} \mathrm{~N}$, classified into five size cla'ses $(0,<200 \mu \mathrm{m}$; I: $200-500 \mu \mathrm{m}$; II: 500 - $1000 \mu \mathrm{m}$; III: $1000-2000 \mu \mathrm{m}$; IV > 2000 ' In', for each area: Continental Shelf, Slope and Oceanic islands.

\begin{tabular}{ccc}
$\begin{array}{c}\text { Ri sponse } \\
\text { variable }\end{array}$ & $P$-value & Post hoc \\
\hline \multicolumn{3}{c}{ Shelf } \\
\hline$\delta^{13} \mathrm{C}$ & $<0.01$ & $\mathrm{II} \neq \mathrm{IV} ; \mathrm{II} \neq 0$ \\
$\delta^{15} \mathrm{~N}$ & $<0.01$ & $\mathrm{I} \neq \mathrm{III}=\mathrm{IV}$ \\
\hline \multicolumn{3}{c}{ Slope } \\
\hline$\delta^{13} \mathrm{C}$ & $>0.05$ & n.s \\
$\delta^{15} \mathrm{~N}$ & $<0.001$ & $\mathrm{I} \neq 0 ; \mathrm{IV}=\mathrm{II}=\mathrm{III}>\mathrm{I}$ \\
\hline & Oceanic islands \\
\hline$\delta^{13} \mathrm{C}$ & $<0.001$ & $\mathrm{IV}>0=\mathrm{I}=\mathrm{II}=\mathrm{III}$ \\
$\delta^{15} \mathrm{~N}$ & $>0.05$ & n.s \\
\hline
\end{tabular}


Table 3. Slope values of trophic level (TL) vs body size (ESD, $\mu \mathrm{m})$, testing two different trophic enrichment factors $(\mathrm{TEF}=3.2$ and 2.3$)$, for each area $( \pm$ standard errors).

\begin{tabular}{|c|c|c|}
\hline \multirow{2}{*}{} & \multicolumn{2}{|c|}{ Slope $\left(\mathrm{TL} \log _{10}(\mu \mathrm{m})^{-1}\right)$} \\
\cline { 2 - 3 } & TEF 2.3 & TEF 3.2 \\
\hline Shelf & $0.58 \pm 0.14$ & $0.42 \pm 0.10$ \\
\hline Slope & $0.85 \pm 0.18$ & $0.61 \pm 0.1$ ? \\
\hline Oceanic Islands & $0.44 \pm 0.08$ & $0.31 \pm 0$. \\
\hline All & $0.59 \pm 0.08$ & $0.42 \pm 0.2$ \\
\hline
\end{tabular}

Table 4. Predator/prey mass ratio (PPMR) and $\mathrm{f}$ - eda or/prey size ratio (PPSR) testing two different trophic enrichment factors (TEF $=32$ and 2.3), for each area.

\begin{tabular}{|c|c|c|c|c|}
\hline & \multicolumn{2}{|c|}{$\overline{T E}+\overline{2} 3$} & \multicolumn{2}{|l|}{ TEF 3.2} \\
\hline & PPMR & PPSR & PPMR & PPSR \\
\hline Shelf & $142.7 \Re$ & 52 & $13,625,858$ & 293 \\
\hline Slope & 3226 & 14 & 75,932 & 42 \\
\hline Oceanic Islands & $6,4,7,294$ & 185 & $3,021,138,554$ & 1,445 \\
\hline All & 121,547 & 49 & $13,894,955$ & 240 \\
\hline
\end{tabular}




\section{Highlights}

- Maximum zooplankton abundance and biovolume was found at the continental slope.

- $\quad \mathrm{POM}$ showed lower $\delta^{13} \mathrm{C}$ than zooplankton, indicating selective feeding.

- Zooplankton $\delta^{15} \mathrm{~N}$ and trophic level increased wi body size.

- Using a $\delta^{15} \mathrm{~N}$ trophic enrichment factor ab ve 2.3 leads to unrealistic estimates. 
Figure 1

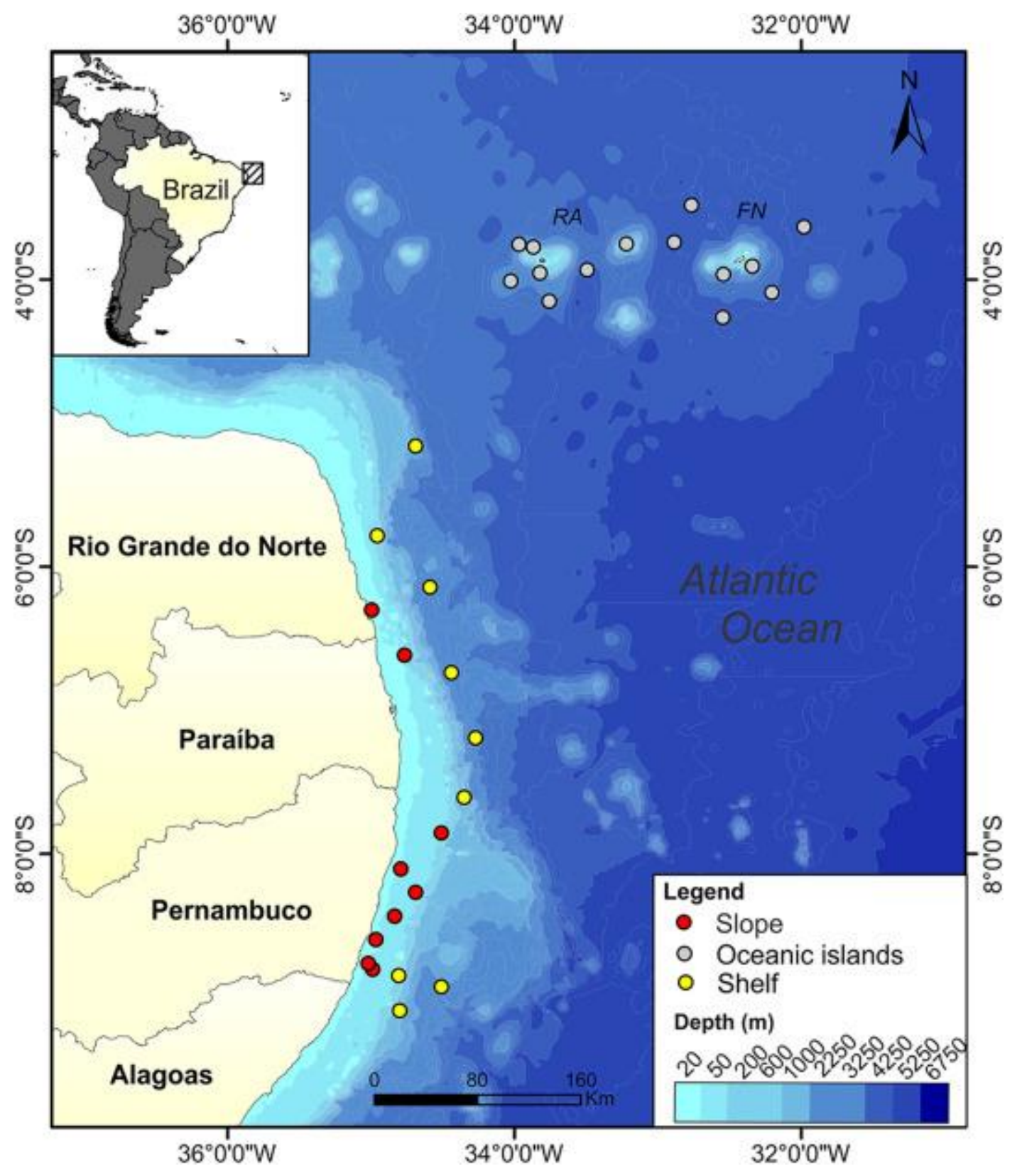


Figure 2

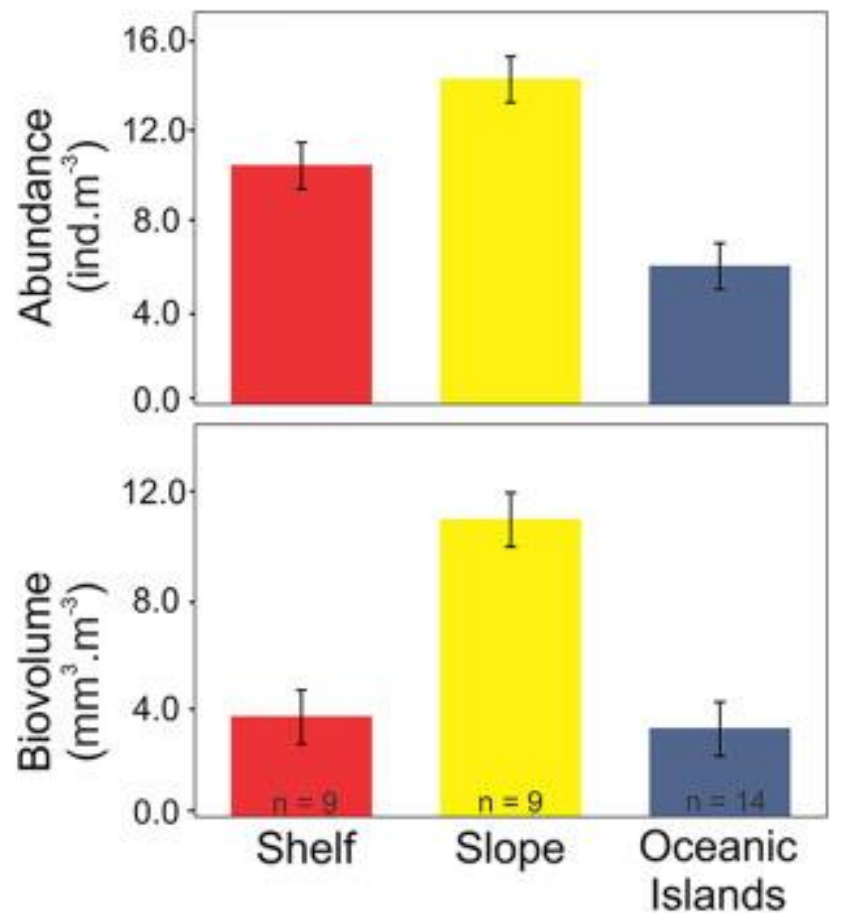

Figure 3
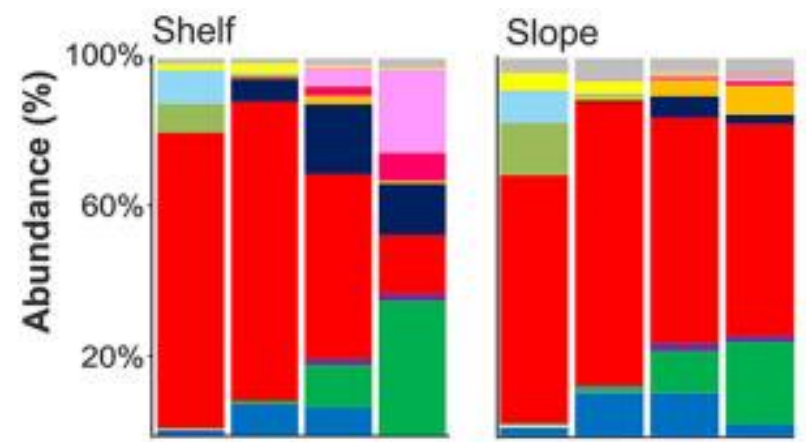

Oceanic Islands
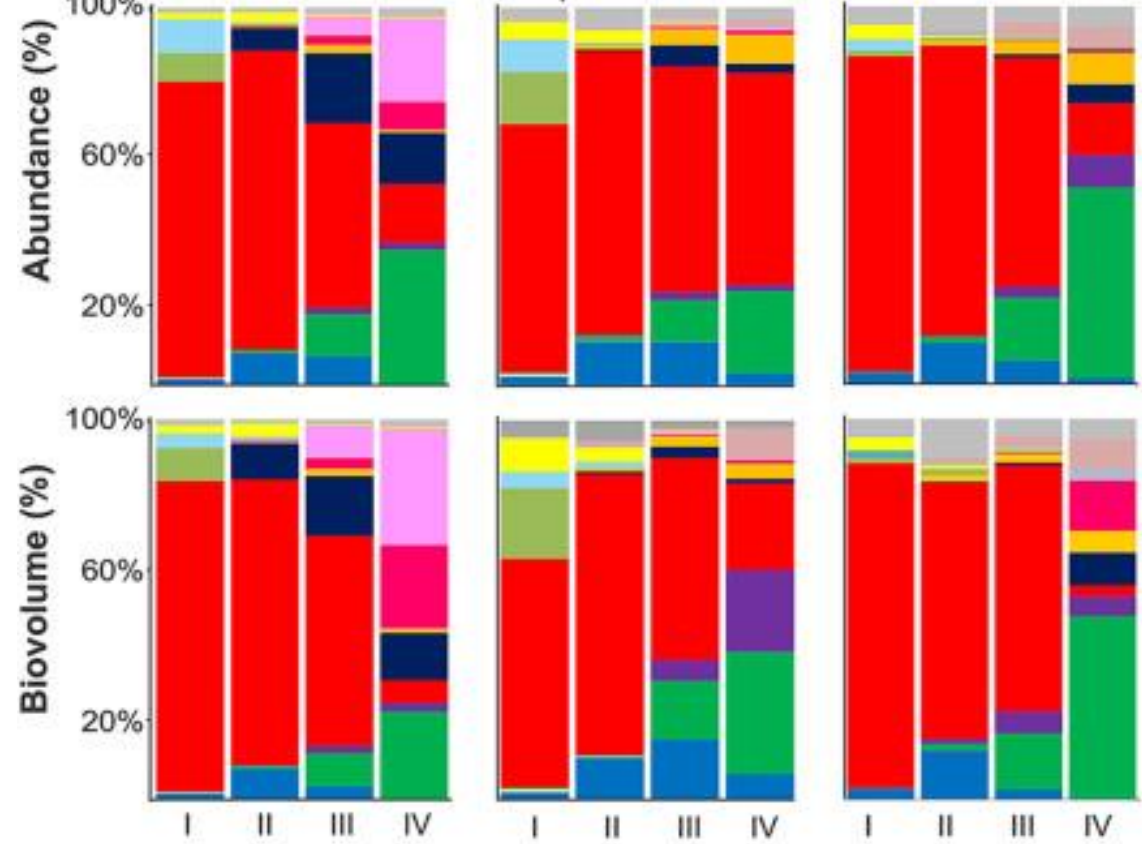

Size Classes

\begin{tabular}{|c|c|c|c|c|}
\hline Bivalvia & Eggs & Eastropoda & Eecapoda & EChaetognatha \\
\hline & Nauplii & Eish Larvae & Ecopepoda & Zooplankton Others \\
\hline & Mysidacea & Euphausiacea & 를ellyfish & Appendicularia \\
\hline
\end{tabular}


Figure 4

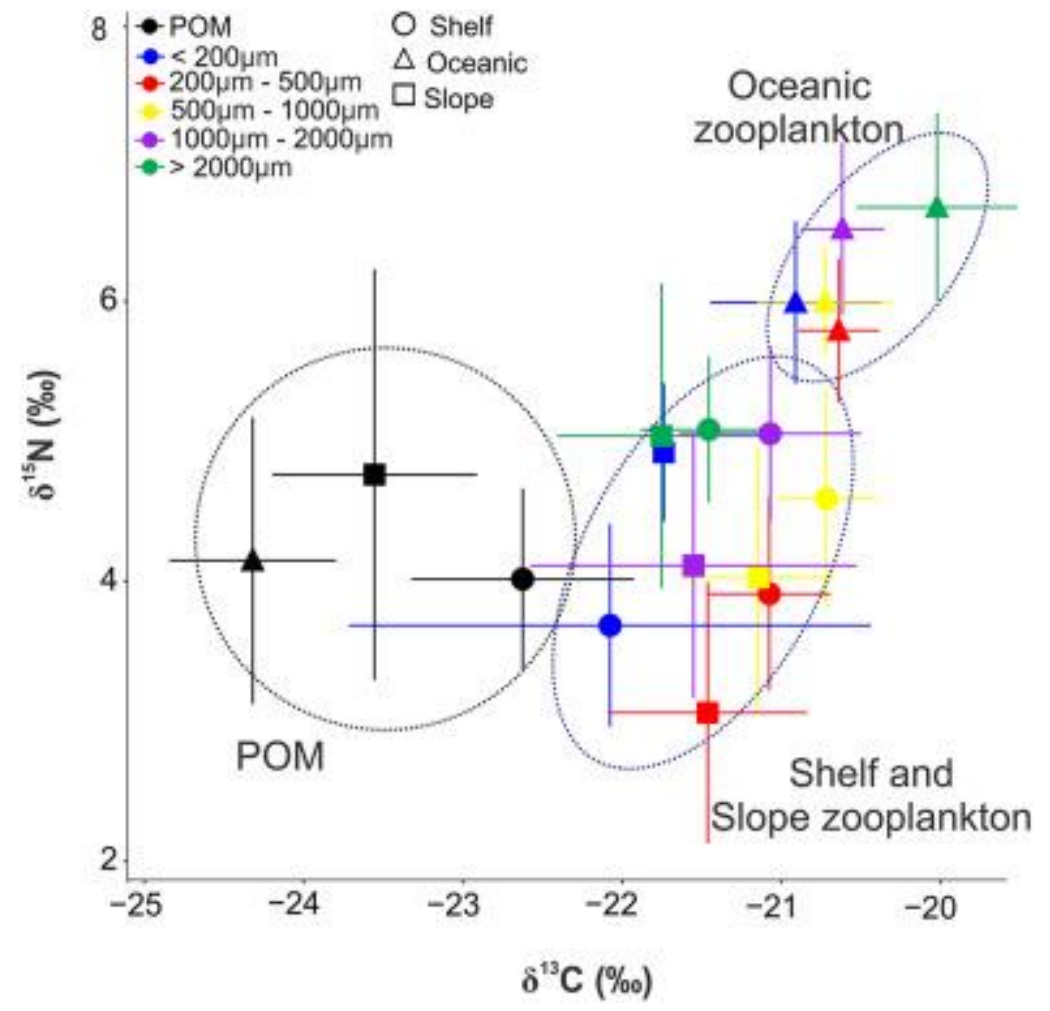


Figure 5

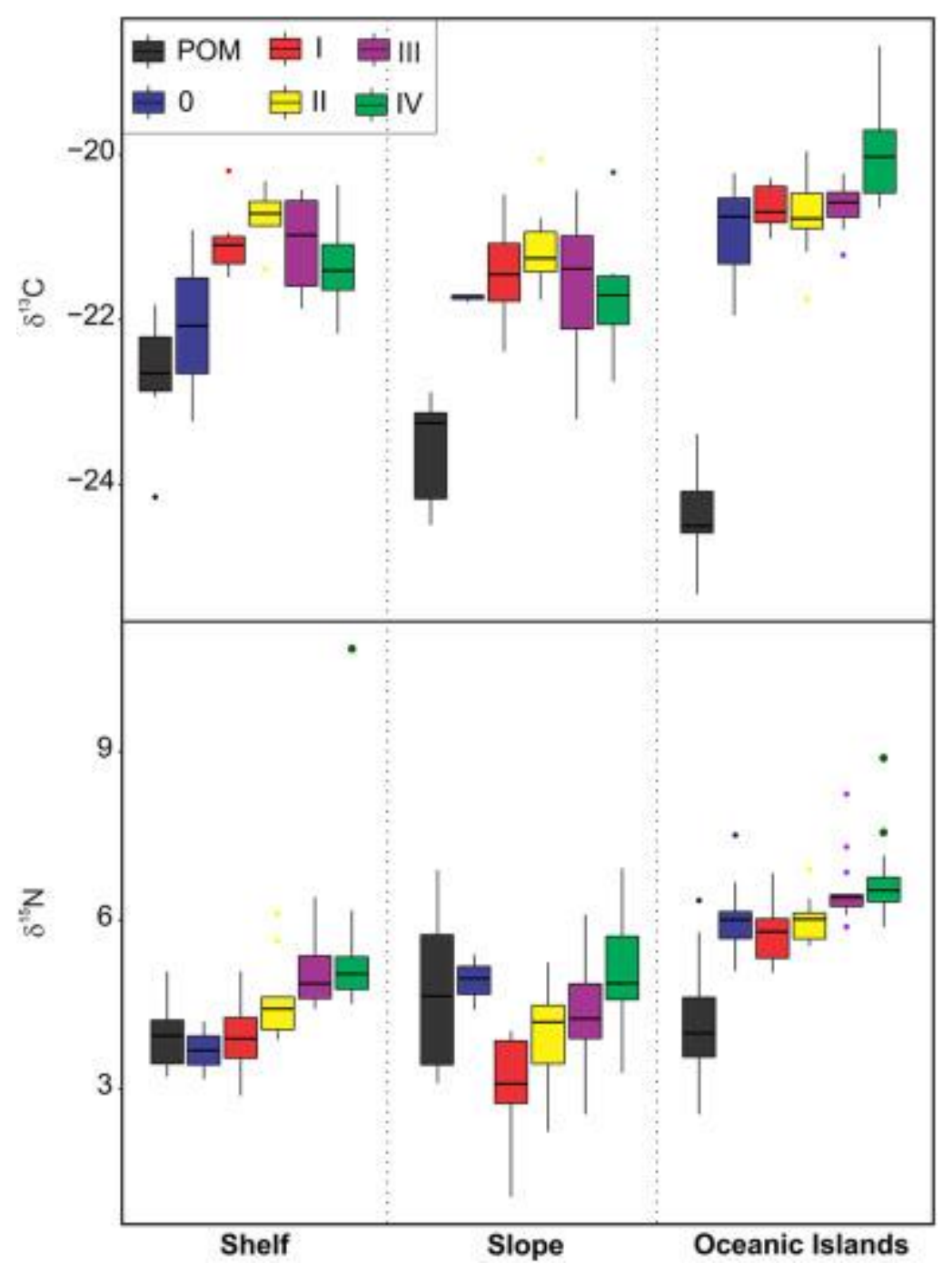


Figure 6

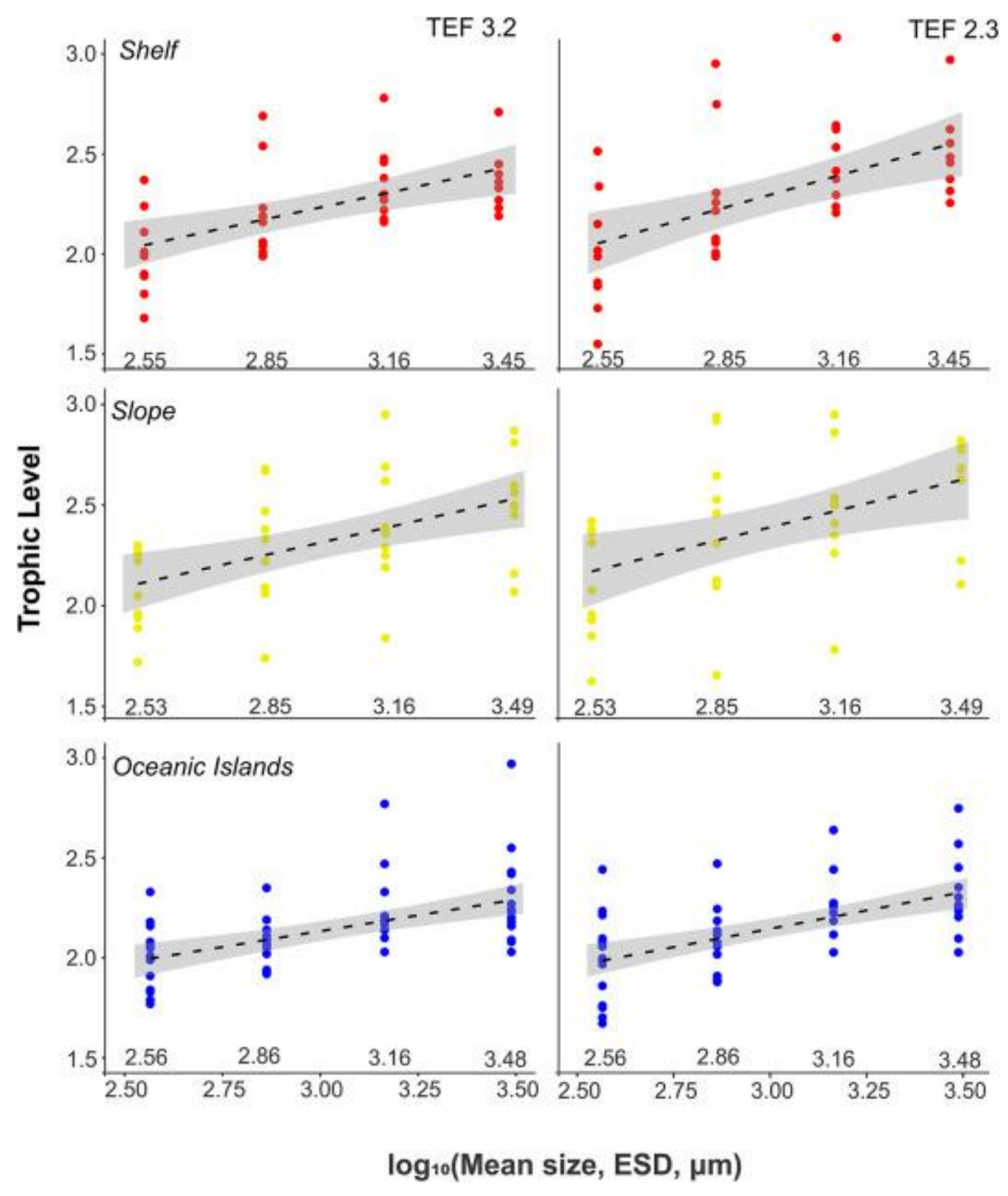

